\title{
First Record of Lissocarcinus polybioides Adams \& White, 1849 (Crustacea: Decapoda: Brachyura: Portunidae) for the United Arab Emirates and the Gulf of Oman
}

\author{
Fadi Yaghmour $^{1 *}$ and Brendan Whittington-Jones ${ }^{2}$
}

\begin{abstract}
Lissocarcinus polybioides Adams \& White, 1849 is a species of swimming crab from the Portunidae family that is known to occur in sub-tidal waters at depths of 2-100 m on muddy/sandy substrate with shells. There it occurs free living, associated with hard corals or associated with sea star Luidia maculata. Studies in the past have reported the presence of L. polybioides in several areas including the coastal waters of Saudi Arabia and Bahrain in the Arabian Gulf. Here, it is reported for the first time from the Alqurm Wa Lehhaffaiiah Protected Area in the United Arab Emirates where a specimen was found on a stranded L. maculata. The identification of the species was conducted using morphologic keys. This study represents the first record of L.polybioides from the coastal waters of the United Arab Emirates and the Gulf of Oman.
\end{abstract}

\section{Background}

On the 1st of April 2017 several sea stars were found stranded on the beach of the Alqurm Wa Lehhaffaiiah Protected Area in the city of Kalba, Sharjah, United Arab Emirates. These were sampled by Environment and Protected Areas Authority Scientific Research Department staff for species identification, subsequently made with identification guides and keys from available literature (Price 1983; Spiegel et al. 1998; Chao 2000).

Most of the sea stars sampled were identified as Astropecten sp. and two specimens were identified as Luidia maculata Müller \& Troschel, 1842. One specimen from the latter species had a small crab sitting on its dorsal body wall around the central disc area; this was sampled as well. The crab was identified as Lissocarcinus polybioides, a species of swimming crab that is known to occur in the waters of Madagascar, Seychelles, India, Sri Lanka, Indonesia, Philippines, Japan, Australia, New Caledonia,

\footnotetext{
* Correspondence: fadi.mohd@epaa.shj.ae

'Scientific Research Department, Environment and Protected Areas Authority, Hefaiyah Mountain Conservation Centre, Sharjah, United Arab Emirates Full list of author information is available at the end of the article
}

Vanuatu, the Andaman Sea, the Red Sea and the Arabian Gulf (Naderloo 2017). In the Arabian Gulf, it was observed in the coastal waters of Saudi Arabia (Apel and Spiridonov 1998) and Bahrain (Mohammed and Al-Ssadh 1996). There has been no previous records of Lissocarcinus polybioides occurring in the coastal waters of the entire Gulf of Oman nor on either coasts of the United Arab Emirates (Naderloo 2017). Therefore, this study represents the first documented record of Lissocarcinus polybioides in the United Arab Emirates and the Gulf of Oman.

\section{Methods}

Study site

The Alqurm Wa Lehhaffaiiah Protected Area was declared a protected area in March 2012 for being an area of high biodiversity that houses significant species of global importance. It was therefore also designated as a Ramsar site for wetlands of international importance in 2013 (Ramsar 2013). The Khor Kalba section of the Alqurm Wa Lehhaffaiiah Protecteed Area is located on the Gulf of Oman on the east coast of the Sharjah Emirate of the 
United Arab Emirates. It has a tidal inlet $(25.013662 \mathrm{~N}$, 56. $359,772 \mathrm{E}$ ) leading to a series of channels fringed with mangrove woodlands of grey mangrove Avicennia marina (Forsk.) Vierh.

The substrate of the channels includes sandy bottoms, seagrass/ algal beds, and rocky reefs with some sparse coral development. Sub-tidal and intertidal mudflats and rocky reefs lie next to the terrestrial habitat which largely comprises of saltmarshes associated sabkhas and other halophytic plant communities, small sand dunes and a $5.5 \mathrm{~km}$ sandy beach that is met by breakwaters at both ends.

\section{Specimen sampling}

Sea star and crab specimens were found stranded on the beach of the Alqurm Wa Lehhaffaiiah Protected Area. The sea stars were preserved by drying them and the crab was stored in $70 \%$ Ethanol solution.

\section{Sample analysis}

The crab specimen was identified visually using a Dino-Lite AM7915MZT digital microscope as well as available identification guides and keys (Apel and Spiridonov 1998; Naderloo 2017).

\section{Results}

\section{SYSTEMATICS}

\section{Phylum ARTHROPODA}

Class CRUSTACEA

Order DECAPODA

Family PORTUNIDAE

Genus Lissocarcinus

Species polybioides Adams \& White, 1849 (Fig. 1b)

\section{Morphology (see Fig. 2)}

The carapace width is slightly broader than carapace length; according to Apel and Spiridonov (1998), the carapace width/carapace length ratio equals to 1.1 which is about the ratio found in our specimen (Carapace Width: $15.5 \mathrm{~mm}$; Carapace Length: $14.0 \mathrm{~mm}$ ). The carapace has an overall pentagonal body shape with a smooth surface with only a pair of short epibranchial ridges starting from the base of the last anterolateral tooth on each side of the carapace. The front is pronounced and broadly triangular with a well-defined notch in its center. The anterolateral borders consist of five anterolateral teeth. These decrease in size from first (anterior) to fifth (posterior) tooth. Posterolateral borders of the carapace converge into a curve. The posterior border is concave (Apel and Spiridonov 1998).

The chelipeds are equal and somewhat stout. The carpus has a spine on inner angle and three smaller spines on the outer surface. The manus has a smooth surface interrupted by two crests on the upper surface. The walking legs are

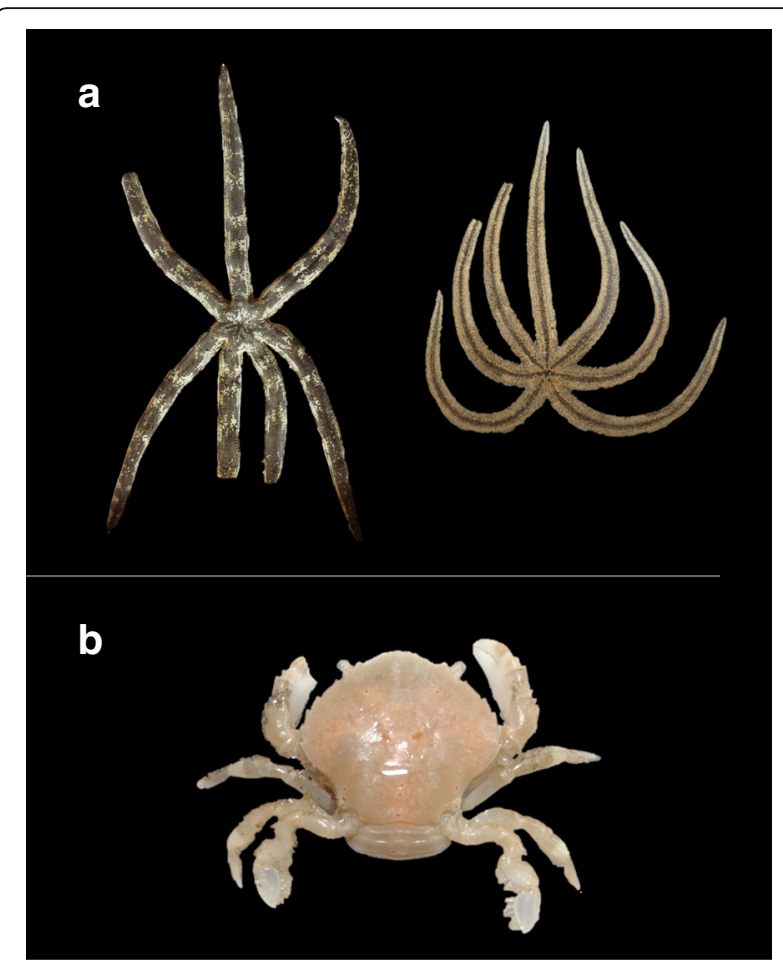

Fig. 1 Samples collected from the Alqurm Wa Lehhaffaiiah Protected Area Beach on the 1st of April 2017: dried Luidia maculata specimen (a) and fresh Lissocarcinus polybioides specimen (b)

firm and rather compressed (Naderloo 2017; Apel and Spiridonov 1998).

Natatory legs with merus about twice as long as broad without any spines. Propodus with both margins smooth and unarmed, but with fringes of hair (Apel and Spiridonov 1998).

\section{Discussion}

Lissocarcinus polybioides have been reported from several localities in the Indo-Pacific region. Our specimen (when fresh) had two orange blotches in the center of the carapace around the metagastric region. This may be similar to descriptions by Adams \& White (1849) and Leene (1938) who describe round markings on the carapace (Apel and Spiridonov 1998). Our specimen also shared features with Sakai (1976) who describes it as dirty creamy ground color with small red spots on the carapace especially along the posterior and lateral margins (Apel and Spiridonov 1998).

This Species is known to occur at depths between 2 and $100 \mathrm{~m}$ in substrates described as sandy and muddy with shells. Many species of the Lissocarcinus genus are known to have symbiotic relations with other species (Rajan et al. 2012). Lissocarcinus laevis is symbiotically associated with sea anemones (Allen 2000; Rajan et al. 2012) and is a facultative commensal to anemones of the 

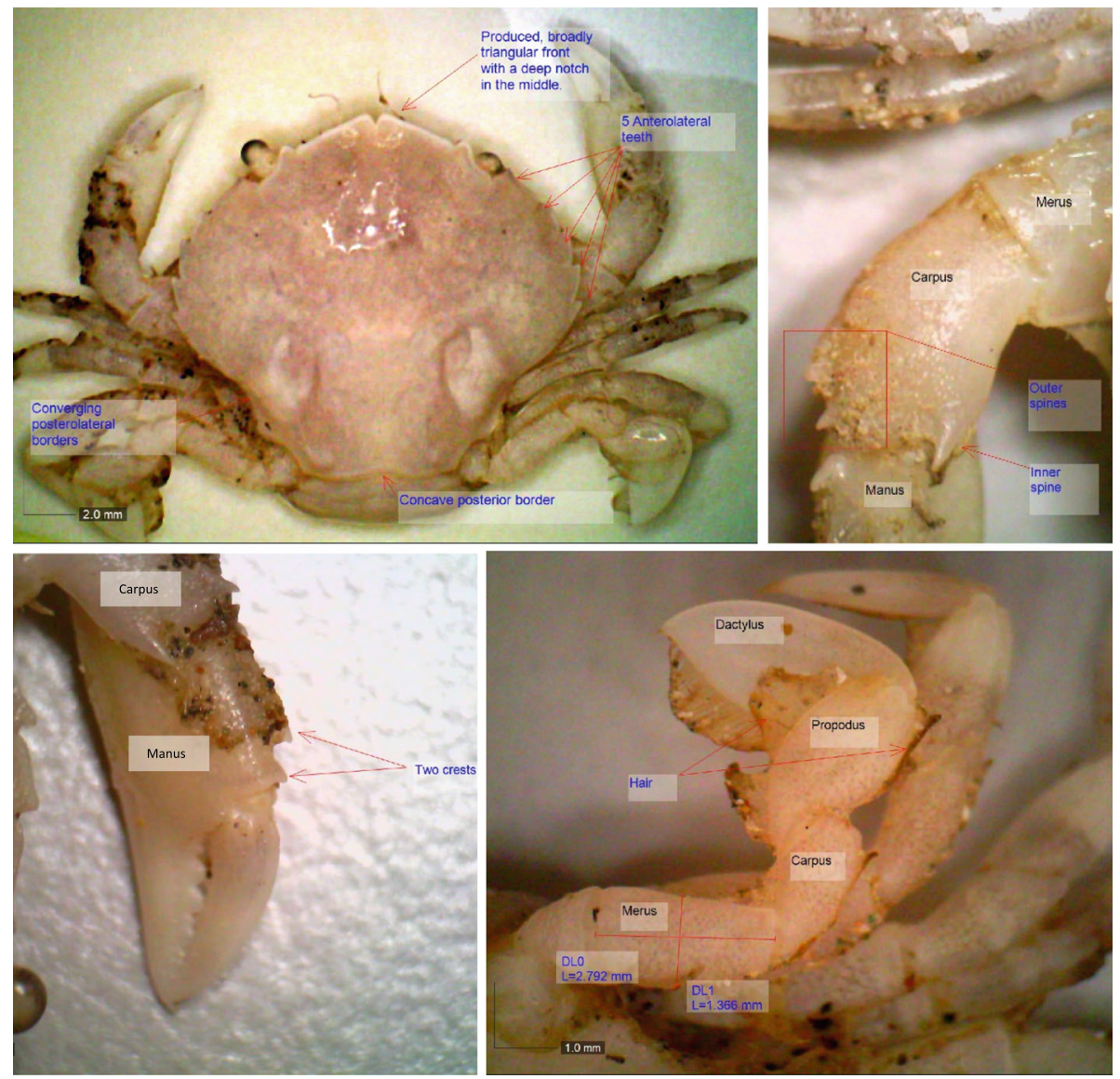

Fig. 2 Various morphologic features of the L. polybioides specimen collected from the beach of the Alqurm Wa Lehhaffaiiah Protected Area: Carapace features (top left), carpus of the right cheliped (top right), marus of the left cheliped (bottom left) and the left natatory leg (bottom right)

Cerianthus genus (Spiridonov 1999; Rajan et al. 2012), Lissocarcinus arkati is a facultative commensal to an unknown sea urchin specie (Spiridonov 1999; Rajan et al. 2012) and Lissocarcinus orbicularis is a commensal to the several species of sea urchin and holothurians such as Actinophyga mauritiana (James 1995; Eeckhaut et al. 2004; Ng and Jeng 1999; Spiridonov 1999). L. polybioides is no different, despite being known to occur free living, it's also associated with hard corals and the sea star Luidia maculata. Specimens of L. polybioides from the Chennai Sea were observed to be attached to the central discs of L.maculata, with very occasional movements on the arms, though, never all the way to the distal ends. The crabs were never observed to leave the sea star even as it buried itself in the sediment. Whenever they were unwittingly detached they would immediately make their way back to the sea star (Rajan et al. 2012). Our specimen was observed to be attached to a stranded sea star L. maculata suggesting that a part of the L. polybioides population occurring along the Gulf of Oman may also be symbiotically associated with this sea star specie.

\section{Acknowledgements}

The authors expresses their gratitude for the support of His Highness Sheikh Dr. Sultan bin Mohammed Al Qasimi, Supreme Council Member and Ruler of Sharjah. The authors would also like to acknowledge the support of her Excellency Hana Saif Al Suwaidi, Chairperson of Sharjah Environment and Protected Areas Authority, and the members of the EPAA Scientific Research Department.

\section{Authors' contributions}

FY made the initial discovery of the specimen. FY and BWJ both worked on identification of the species. Both authors have contributed in writing the manuscript and have read and approved the final manuscript.

\section{Ethics approval and consent to participate}

In this study all examined specimens were standings collected by authorized staff of the Environment and Protected Areas Authority Scientific Research Department. No ethics approval was required by our internal ethics committee.

\section{Competing interests}

The authors have no competing interests to declare.

\section{Publisher's Note}

Springer Nature remains neutral with regard to jurisdictional claims in published maps and institutional affiliations. 


\section{Author details}

'Scientific Research Department, Environment and Protected Areas Authority, Hefaiyah Mountain Conservation Centre, Sharjah, United Arab Emirates.

${ }^{2}$ Scientific Research Department, Environment and Protected Areas Authority,

Sharjah Desert Park, Sharjah, United Arab Emirates.

Received: 22 December 2017 Accepted: 29 May 2018

Published online: 15 June 2018

\section{References}

Allen, G. Marine Life of the Pacific and Indian Ocean: 1-96. Periplus Nature Guides, Perplus editions (HK) Ltd. (2000).

Apel M, Spiridonov V. Taxonomy and zoogeography of the portunid crabs (Crustacea: Decapoda: Brachyura: Portunidae) of the Arabian gulf and adjacent waters. Fauna of Saudi Arabia. 1998;17:150-331.

Chao S-M. New Records of sea Stars (Asteroidea: Echinodermata) from the continental shelf of Taiwan. Zool Stud. 2000;39(3):275-84.

Eeckhaut I, Parmentier E, Becker P, Gomez da Silva S, Jangoux M. Parasites and biotic diseases in field and cultivated sea cucumbers. In: Lovatelli A, editor. Advances in sea cucumber aquaculture and management, vol. 463. Rome: FAO Fisheries Technical Paper; 2004. p. 311-25.

James D. Animal associations in echinoderms. J Mar Biol Ass India. 1995;37(1\&2):272-6.

Mohammed S, Al-Ssadh S. Coral reef grounds and its associated biota in the western side of the Arabian gulf (ROPME Sea area) with respect to 1991 gulf oil spill. Indian J Mar Sci. 1996;25:35-40.

Naderloo R. Atlas of crabs of the Persian Gulf. Cham: Springer; 2017.

Ng PK, Jeng MS. The brachyuran crabs (Crustacea: Decapoda: Eumedonidae and Portunidae) symbiotic with echinoderms in Taiwan. Zool Studies. 1999;38(3):268-74.

Price A. Echinoderms of Saudi Arabia: echinoderms of the Arabian Gulf Coast of Saudi Arabia. Fauna of Saudi Arabia. 1983;5:28-108.

Rajan R, Vencartman C, Siy Aleena G, Paranthaman D. Notes on the Association of Lissocarcinus Polybiodes Adams and White, 1848 (Portunidae, Caphyrinae), With Sea Star Luidia maculata Muller and Troschel, 1842. Rec zool Sur India. 2012;112(2):23-6.

Ramsar. The Ramsar convention on wetlands, 2013. Retrieved from https://www. ramsar.org: https:/www.ramsar.org/news/third-ramsar-site-in-united-arabemirates. Accessed 15 Mar 2013.

Spiegel D, Lane D, Stampanato S, Jangoux M. The asteroid Fauna (Echinodermata) of Singapore, with a distribution table and an illustrated identification to the species. Raffles Bull Zool. 1998;46(2):431-70.

Spiridonov V. Results of the Rumphius Biohistorical Expedition to Ambon (1990). Part 8. Swimming crabs of Ambon (Crustacea: Decapoda: Portunidae). Zool Med Leiden. 1999;73(4):63-97.

\section{Ready to submit your research? Choose BMC and benefit from:}

- fast, convenient online submission

- thorough peer review by experienced researchers in your field

- rapid publication on acceptance

- support for research data, including large and complex data types

- gold Open Access which fosters wider collaboration and increased citations - maximum visibility for your research: over $100 \mathrm{M}$ website views per year

At BMC, research is always in progress.

Learn more biomedcentral.com/submissions 